\title{
Dinâmica da mobilização de elementos em solos da Amazônia submetidos à inundação ${ }^{1}$
}

\author{
Hedinaldo Narciso LIMA², Jaime Wilson Vargas de MELLO³; Carlos Ernesto G. R. SCHAEFER ; João Carlos KER ${ }^{3}$
}

\section{RESUMO}

Parte significativa de solos da Amazônia permanece saturada ou inundada por períodos que podem variar de alguns dias a vários meses, em decorrência de enchentes ou deficiência de drenagem em algumas áreas, resultando em alterações químicas, físicas e biológicas nos solos. Este trabalho foi conduzido com o objetivo de avaliar a dinâmica da mobilização de Al, $\mathrm{Ca}, \mathrm{Fe}, \mathrm{K}, \mathrm{Mg}, \mathrm{Mn}$, $\mathrm{Na}$, Si e P em solos da Amazônia submetidos a inundação. Amostras de vários solos foram submetidas à inundação durante seis meses. Alíquotas da solução foram coletadas periodicamente durante o tempo de inundação e determinaram-se os teores dos diversos elementos em solução. A inundação influenciou a cinética dos elementos, com aumento da mobilização dos mesmos, principalmente, nas primeiras semanas. Os teores de Fe em solução foram mais elevados para os solos mais ricos em Fe amorfo. Em amostras com baixos teores de Fe amorfo e baixo conteúdo de matéria orgânica, os teores de Fe em solução foram muito reduzidos. O teor de $\mathrm{P}$ em solução foi influenciado por todas as formas de $\mathrm{P}$. O P ligado ao $\mathrm{Fe}$ foi a forma que maior influência exerceu sobre o teor de P solúvel. Os teores dos cátions $\mathrm{Ca}, \mathrm{Mg}, \mathrm{Ke} \mathrm{Na}$, em solução, foram diretamente influenciados por seus respectivos teores trocáveis, bem como pela cinética do Fe e do Mn.

\section{PALAVRAS CHAVES}

Cinética; alterações ambientais; ecossistemas amazônicos; solos de várzea.

\section{Dinamics of elements in soils from Amazonia after controlled inundation}

\begin{abstract}
Significant part of Amazonia soils stays partially or completely waterlogged for varying periods of days to months, as result of widespread inundation or drainage deficiency in some areas, causing changes in chemical, physical and biological properties. In this work, we aimed to evaluate the dynamics of mobilization of $\mathrm{Al}, \mathrm{Ca}, \mathrm{Fe}, \mathrm{K}, \mathrm{Mg}, \mathrm{Mn}, \mathrm{Na}, \mathrm{Si}$, P in soils subjected to controlled six months inundation. Soil solution aliquots were collected periodically during the inundation period, determining all elements in solution. The inundation influenced the kinetics of elements, increasing their mobilization, notably in the first weeks. Levels of Fe in solution were higher in soils with greater amounts of amorphous Fe. In soils with low amorphous Fe and low organic matter contents, mobilization of Fe was very low. Levels of $P$ in solution were influenced by all P forms, but Fe-P forms exerted the greatest influence on mobilized P. Levels of $\mathrm{Ca}, \mathrm{Mg}$, Kand $\mathrm{Na}$ in solution were directly influenced by their exchangeable levels, as well by the Mn and Fe kinetics.
\end{abstract}

\section{KEYWORDS}

Amazon soils, kinetics, soil waterlogging, amazon ecosystems.

\footnotetext{
${ }^{1}$ Parte da Tese de Doutorado do primeiro autor apresentada ao Programa de Pós-Graduação em Solos e Nutrição de Plantas da Universidade Federal de Viçosa. Trabalho financiado pelo CNPq. Enviado para publicação em setembro de 2004.

${ }^{2}$ Professor Adjunto - Universidade Federal do Amazonas. Faculdade de Ciências Agrárias. Av. Gen. Rodrigo Otávio, 3.000. CEP 69077-000. Manaus-AM. hedinaldo@ufam.edu.br

${ }^{3}$ Professor Adjunto-Universidade Federal de Viçosa. Departamento de Solos. Av. P. H. Rolfs. UFV-Viçosa-MG.
} 


\section{INTRODUÇÃO}

Parte importante dos solos da Amazônia pode permanecer saturada ou inundada por períodos que variam de alguns dias a alguns meses, como resultado das inundações sazonais decorrentes da elevação do nível das águas durante o período de cheia dos rios da região, ou de elevadas precipitações pluviais, de restrições de drenagem ou de a elevação do nível do lençol freático.

A inundação altera o equilíbrio dos elementos e dos compostos no solo, resultando em importantes mudanças químicas, físicas, biológicas e mineralógicas, das quais a mais significativa é, possivelmente, o decréscimo no potencial eletroquímico de elétrons ou potencial redox. Outras alterações importantes são aumento do $\mathrm{pH}$ nos solos ácidos e decréscimo nos solos alcalinos, mudanças na condutividade elétrica, na força iônica e na sorção e dessorção de íons (Reddy e Patrick Jr., 1975; Yu, 1991; Olivie-Lauquet et al., 2001). A magnitude dessas alterações depende de características do solo como $\mathrm{pH}$ inicial, teores de ferro e de manganês, conteúdo de matéria orgânica e grau de cristalinidade dos óxidos presentes (Mello et al., 1992).

O potencial redox ou atividade de elétrons influencia $o$ estado de oxidação do hidrogênio, carbono, nitrogênio, oxigênio, enxofre, manganês, ferro, cobalto e cobre no sistema aquoso e, representa uma medida quantitativa da tendência de um dado sistema oxidar ou reduzir substâncias ou elementos susceptíveis a esses fenômenos. Valores altos e positivos do potencial indicam uma baixa atividade de elétrons e, portanto, condições oxidantes; enquanto valores baixos e negativos do potencial, condições redutoras. Um sistema natural raramente alcançará o equilíbrio entre oxidação e redução, em razão da contínua adição de doadores de elétrons, isto é, compostos orgânicos oxidáveis (Bohn, 1970).

Após a inundação, o suprimento de oxigênio para o solo é drasticamente reduzido (Willett, 1991; McLatchey e Reddy, 1998). Em pouco tempo de inundação, bactérias aeróbicas e reações químicas de oxidação consomem todo o oxigênio disponível na água, reduzindo seu nível rapidamente em várias regiões do solo (Liesack et al., 2000), o que o torna virtualmente desprovido de oxigênio (Ponnamperuma, 1972). Sob redução, intensifica-se a atividade biológica anaeróbica e uma diversidade de substâncias redutoras é produzida, sem as quais a redução de compostos inorgânicos não ocorreria (Yu, 1991).

Na ausência de oxigênio, receptores alternativos de elétrons passam a ser usados. A ordem, na qual os receptores de elétrons são usados por uma população microbiana, segue geralmente o conceito de energia livre, resultando na seguinte seqüência: respiração aeróbica (redução do oxigênio), redução do nitrato, redução de óxidos metálicos, redução do sulfato e redução do bicarbonato (McLatchey e Reddy, 1998; Liesack et al., 2000).

A liberação de oxigênio na rizosfera de determinadas plantas e a difusão através da água de superfície criam um gradiente redox ao redor das raízes e nos primeiros milímetros dos solos inundados. O oxigênio na superfície do solo e ao longo das raízes é um fator-chave no controle de receptores alternativos de elétrons, como nitrato, manganês, ferro e sulfato. Na presença de oxigênio, esses receptores são regenerados pela oxidação de suas formas reduzidas.

Este trabalho foi conduzido com os objetivos de avaliar as alterações na mobilização de alguns nutrientes e outros elementos de importância ambiental em diferentes solos da Amazônia submetidos à inundação e discutir as implicações ambientais e agronômicas decorrentes dos processos redox nesses solos.

\section{MATERIAL E MÉTODOS}

Utilizaram-se neste estudo amostras de onze diferentes solos, os quais foram classificados de acordo com o Sistema Brasileiro de Classificação de Solos (Embrapa, 1999): Argissolo Amarelo com horizonte A antrópico (PA); Latossolo Amarelo com horizonte A antrópico (LA); Cambissolo com horizonte A antrópico (CAA); Latossolo Amarelo distrófico típico (LAd); Latossolo Amarelo distrófico petroplíntico (LAdc); Plintossolo Háplico distrófico típico (FXd); Gleissolo Háplico Ta eutrófico (GXve); e Neossolo Flúvico Ta eutrófico (RUve), do Médio Amazonas; Alissolo Hipocrômico argilúvico (APt); Plintossolo Argilúvico alumínico abrúptico (FTa); Neossolo Flúvico Ta eutrófico (RUve), do Alto Solimões.

Os solos utilizados foram reunidos em quatro diferentes grupos para mais bem visualizar o fenômeno de mobilização dos elementos avaliados em ambientes com diferentes características, embora estejam inseridos em uma paisagem ampla e não dissociada, onde, portanto, uns influenciam os outros. O agrupamento foi feito, levando-se em consideração algumas das características químicas e mineralógicas, as características de drenagem e posição na paisagem.

Os grupos foram assim constituídos: 1 - solos de várzea (Neossolo Flúvico Ta eutrófico, do Médio Amazonas, Neossolo Flúvico Ta eutrófico, do Alto Solimões e Gleissolo Háplico Ta eutrófico); 2 - Latossolos (Latossolo Amarelo distrófico típico e Latossolo Amarelo distrófico petroplíntico) 3 - solos antropogênicos (Argissolo Amarelo com horizonte A antrópico, Latossolo Amarelo com horizonte A antrópico e Cambissolo com horizonte A antrópico); e 4 - Plintossolos e Alissolo (Plintossolo Háplico distrófico típico, Plintossolo Argilúvico alumínico abrúptico e Alissolo Hipocrômico argilúvico).

Amostras dos horizontes superficial e subsuperficial dos diferentes solos foram secas ao ar e peneiradas em malhas de $2 \mathrm{~mm}$ de abertura para obtenção da terra fina seca ao ar (TFSA) e foram analisadas de acordo com procedimento descrito em Embrapa (1997) para caracterização química de rotina. Determinaram-se, ainda, os teores de Fe por ditionito-citrato de sódio $\left(\mathrm{Fe}_{\mathrm{d}}\right)$ (Coffin, 1963) e por oxalato ácido de amônio ( $\mathrm{Fe}_{\mathrm{o}}$ ) (Schwertmann, 1964) e o carbono orgânico total do solo e das substâncias húmicas (Yeomans e Bremner, 1988) (Tabela 1).

Em frasco de polietileno, foram colocados $300 \mathrm{~g}$ de terra fina seca ao ar e, em seguida, adicionou-se, lentamente, água deionizada até completa saturação do solo. As amostras foram 
Tabela 1 - Características químicas dos solos estudados

\begin{tabular}{|c|c|c|c|c|c|c|c|c|c|c|}
\hline Horizonte & $\mathrm{pH}$ & $\mathrm{P}$ & $\mathrm{K}^{+}$ & $\mathrm{Na}^{+}$ & $\mathrm{Ca}^{2+}$ & $\mathrm{Mg}^{2+}$ & $\mathrm{Al}^{3+}$ & $\mathrm{Fe}_{0}$ & $\mathrm{Fe}_{\mathrm{d}}$ & COT \\
\hline & & \multicolumn{3}{|c|}{$\mathrm{mg} \mathrm{kg}^{-1}$} & \multicolumn{3}{|c|}{$\mathrm{cmolc} \mathrm{kg}^{-1}$} & \multicolumn{3}{|c|}{$\mathrm{g} \mathrm{kg}^{-1}$} \\
\hline \multicolumn{11}{|c|}{ Grupo 1 - Solos de várzea } \\
\hline \multicolumn{11}{|c|}{ Gleissolo Háplico Ta eutrófico - GXve } \\
\hline $\bar{A}$ & 4,84 & 69 & 46 & 38 & 9,86 & 3,21 & 2,50 & 15,00 & 25,70 & 8,30 \\
\hline C & 6,51 & 33 & 44 & 80 & 13,01 & 7,37 & 0,08 & 10,50 & 23,90 & 4,90 \\
\hline \multicolumn{11}{|c|}{ Neossolo Flúvico Ta eutrófico - RUve (MA) } \\
\hline $\mathrm{A}$ & 5,40 & 25 & 79 & 32 & 10,62 & 2,52 & 0,51 & 11,80 & 23,60 & 9,70 \\
\hline $\mathrm{C}$ & 5,60 & 45 & 44 & 63 & 11,17 & 3,44 & 0,42 & 11,50 & 25,20 & 5,50 \\
\hline \multicolumn{11}{|c|}{ Neossolo Flúvico Ta eutrófico - RUve (AA) } \\
\hline$A$ & 5,38 & 92 & 300 & 186 & 9,04 & 3,34 & 0,19 & 11,40 & 23,20 & 20,70 \\
\hline C & 6,41 & 173 & 35 & 48 & 4,04 & 5,62 & 0,13 & 7,80 & 24,30 & 2,80 \\
\hline
\end{tabular}

Grupo 2 - Latossolos

Latossolo Amarelo distrófico petroplíntico - LAdc

\begin{tabular}{|c|c|c|c|c|c|c|c|c|c|c|}
\hline $\bar{A}$ & 4,71 & 2 & 16 & 0 & 0,01 & 0,03 & 1,63 & 2,70 & 35,90 & 14,8 \\
\hline Bw & 4,68 & 1 & 2 & 0 & 0,01 & 0,01 & 0,99 & 0,70 & 40,20 & 5,20 \\
\hline \multicolumn{11}{|c|}{ Latossolo Amarelo distrófico típico - LAd } \\
\hline A & 4,57 & 1 & 15 & 0 & 0,01 & 0,03 & 1,06 & 4,50 & 33,70 & 13,60 \\
\hline Bw & 4,43 & 1 & 2 & 0 & 0,01 & 0,01 & 0,77 & 0,30 & 50,20 & 3,80 \\
\hline
\end{tabular}

\section{Grupo 3 - Solos antropogênicos}

Argissolo Amarelo com horizonte A antrópico - PA

\begin{tabular}{|c|c|c|c|c|c|c|c|c|c|c|}
\hline $\bar{A}$ & 5,20 & 173 & 12 & 0 & 3,85 & 0,63 & 0,19 & 2,60 & 35,70 & 18,30 \\
\hline $\mathrm{Bt}$ & 5,13 & 145 & 4 & 0 & 1,31 & 0,12 & 0,13 & 1,00 & 51,60 & 4,60 \\
\hline \multicolumn{11}{|c|}{ Latossolo Amarelo com horizonte A antrópico - LA } \\
\hline $\bar{A}$ & 6,16 & 1991 & 55 & 51 & 14,13 & 1,32 & 0,00 & 5,50 & 35,20 & 34,60 \\
\hline Bw & 6,49 & 1567 & 27 & 20 & 4,37 & 0,30 & 0,00 & 1,70 & 52,80 & 9,40 \\
\hline \multicolumn{11}{|c|}{ Cambissolo com horizonte A antrópico - CA } \\
\hline A & 6,28 & 1332 & 70 & 55 & 6,59 & 1,04 & 0,00 & 4,40 & 43,60 & 35,30 \\
\hline $\mathrm{Bi}$ & 6,04 & 92 & 18 & 7 & 0,55 & 0,08 & 0,00 & 0,40 & 34,20 & 0,80 \\
\hline
\end{tabular}

Grupo 4 - Plintossolos e Alissolo

Alissolo Hipocrômico argilúvico - APt

\begin{tabular}{|c|c|c|c|c|c|c|c|c|c|c|}
\hline $\bar{A}$ & 5,82 & 4 & 46 & 38 & 9,85 & 2,07 & 0,13 & 4,30 & 35,70 & 23,60 \\
\hline $\mathrm{Bt}$ & 5,41 & 1 & 32 & 28 & 5,42 & 1,14 & 10,82 & 4,00 & 43,30 & 1,10 \\
\hline \multicolumn{11}{|c|}{ Alissolo Hipocrômico argilúvico - APt } \\
\hline $\bar{A}$ & 5,82 & 4 & 46 & 38 & 9,85 & 2,07 & 0,13 & 4,30 & 35,70 & 23,60 \\
\hline $\mathrm{Bt}$ & 5,41 & 1 & 32 & 28 & 5,42 & 1,14 & 10,82 & 4,00 & 43,30 & 1,10 \\
\hline \multicolumn{11}{|c|}{ Plintossolo Argilúvico alumínico abrupto - FTa } \\
\hline $\bar{A}$ & 4,91 & 6 & 57 & 41 & 1,09 & 0,42 & 1,22 & 3,90 & 4,60 & 21,00 \\
\hline $\mathrm{Bt}$ & 4,96 & 1 & 42 & 33 & 0,49 & 0,30 & 11,42 & 5,60 & 22,20 & 1,60 \\
\hline \multicolumn{11}{|c|}{ Plintossolo Háplico distrófico típico - FXd } \\
\hline $\bar{A}$ & 4,30 & 2 & 19 & 17 & 0,00 & 0,06 & 6,24 & 3,50 & 6,00 & 14,40 \\
\hline Bt & 4,48 & 0,3 & 15 & 15 & 0,00 & 0,04 & 8,38 & 4,00 & 51,60 & 5,00 \\
\hline
\end{tabular}

$\mathrm{Fe}_{\mathrm{o}}$ - Fe extraído por oxalato de amônio; $\mathrm{Fe}_{\mathrm{d}}$ - Fe extraído por ditionito; COT - carbono orgânico total; $\mathrm{P}, \mathrm{Ke} \mathrm{Na}-\mathrm{Mehlich} 1$; Ca, Mg e Al trocáveis - KCl 1 mol L-1; pH em água, relação solo/água 1/2,5 


\section{ACTA AMAZONICA}

DINÂMICA DA MOBILIZAÇÃO DE ELEMENTOS EM SOLOS DA AMAZÔNIA SUBMETIDOS À INUNDAÇÃO mantidas submersas, sob uma lâmina de água de, aproximadamente, $1 \mathrm{~cm}$ durante seis meses. Em cada frasco, foi instalada uma pequena mangueira (dreno) com uma pedra porosa na extremidade (pedra de aquário), a qual foi revestida por uma camada de areia, previamente lavada com ácido clorídrico, e envolta por um tecido de algodão. Os frascos foram mantidos fechados com tampas, que possuíam um orifício para a passagem da mangueira, permitindo trocas gasosas.

Alíquotas de solução foram coletadas através do dreno, após 1, 15, 29, 43, 71, 99, 127, 155 e 183 dias de inundação. Depois de cada coleta, o nível de água de cada amostra foi restabelecido com água deionizada. A solução coletada foi filtrada e imediatamente acidificada para $\mathrm{pH}$ próximo de 2 com solução de ácido clorídrico $1 \mathrm{~mol} \mathrm{~L}^{-1}$. Em algumas amostras, principalmente aquelas dos horizontes superficiais, houve floculação de ácidos orgânicos, razão pela qual todas as amostras foram novamente filtradas, após acidificação.

Os teores de $\mathrm{Fe}, \mathrm{Mn}$, Ca e Mg foram determinados por espectrofotometria de absorção atômica; Al e Si por espectrometria de emissão com plasma induzido; Na e K por fotometria de chama e P por colorimetria (Kuo, 1986).

\section{RESULTADOS E DISCUSSÃO}

\section{Ferro}

Como cátion divalente, $\mathrm{o} \mathrm{Fe}^{2+}$ solúvel compete com outros cátions como $\mathrm{Ca}^{2+}, \mathrm{Mg}^{2+}, \mathrm{NH}_{4}^{+}$e $\mathrm{K}^{+}$pelos sítios de troca, $\mathrm{O}$ que acelera a liberação desses para a solução. Em solos fortemente reduzidos, o teor de $\mathrm{Fe}^{2+}$ em solução pode vir a ser muito elevado, particularmente em solos com alto conteúdo de óxidos de Fe amorfos e elevado conteúdo de matéria orgânica.

A dinâmica do Fe no solo após a inundação (Figura 1) revelou comportamento similar em todos os solos avaliados, caracterizada por um rápido aumento inicial do teor em solução, seguido por um decréscimo igualmente rápido, atingindo níveis mais ou menos estáveis 71 dias após a inundação. De modo geral, o pico de máximo teor em solução nos Plintossolos, no Alissolo e nos solos de várzea, exceto o Gleissolo, foi atingido já ao final da segunda semana de inundação, comportamento semelhante foi observado por Jugsujinda et al. (1987). Nos Latossolos este pico foi deslocado para o final da quarta semana.

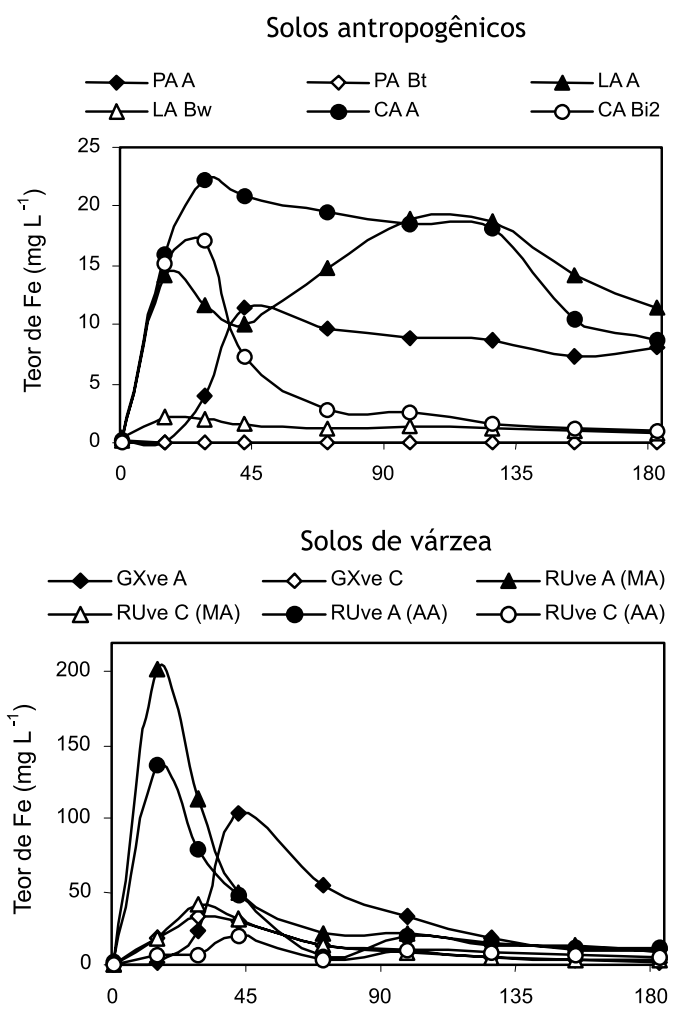

Tempo de inundação (dias)

Figura 1 - Variação nos teores de Fe em solução durante o período de inundação. 


\section{ACTA \\ AMAZONICA}

Com a redução de compostos do solo pela inundação, o $\mathrm{pH}$ aumenta, da mesma forma que aumentam os teores de $\mathrm{Fe}^{2+} \mathrm{e} \mathrm{Mn}^{2+}$ em solução. Admite-se que, quando o $\mathrm{pH}$ dos solos atinge valores próximos a 6,5-7,0, estabelecem-se condições para a reoxidação do $\mathrm{Fe}^{2+}$ por reações químicas e microbiológicas (Ponnamperuma et al., 1967; Liesack et al., 2000).

Observou-se que os teores de Fe em solução foram sempre mais elevados nos horizontes superficiais do que nos horizontes subsuperficiais (Figura 1). Esse comportamento deve-se relacionar aos teores mais elevados de matéria orgânica, tendo consequentemente formas menos cristalinas de óxidos de Fe nos horizontes superficiais, as quais são mais facilmente reduzidas. $O$ fato pode ser constatado pelos coeficientes de correlação positivos e significativos entre o teor de Fe em solução, os teores de Fe extraído por oxalato de amônio (Tabela 2) e a relação $\mathrm{Fe} / \mathrm{Fe}_{\mathrm{d}}$; sendo a correlação negativa e significativa entre o teor de $\mathrm{Fe}$ em solução e os teores de $\mathrm{Fe}_{\mathrm{d}}$ (dados nãoapresentados). Consistentemente, os horizontes subsuperficiais, apesar de possuírem teores mais elevados de óxidos de Fe (Tabela 1), apresentaram teores de $\mathrm{Fe}^{2+} \mathrm{em}$ solução acentuadamente mais baixos do que os horizontes superficiais mais pobres em Fe.

Os maiores teores de Fe em solução foram observados no horizonte superficial do Plintossolo abrupto, seguido do Neossolo Flúvico do Alto Solimões e do Latossolo Amarelo; enquanto os menores teores ocorreram sempre nos horizontes subsuperficiais dos Latossolos e dos Plintossolos.

A redução microbiológica de óxidos de Fe parece ser influenciada pelo grau de cristalinidade (Munch e Ottow, 1980; Phillips et al., 1993) e pela superfície específica dos mesmos (Roden \& Zachara, 1996), com redução preferencial de ferrihidrita e lepidocrocita, em decorrência de sua menor cristalinidade e estabilidade (Liesack et al., 2000). A matéria orgânica do solo também influencia a dinâmica do Fe, tanto por seus efeitos inibidores do processo de cristalinidade dos óxidos de Fe (Schwertmann, 1966; Schwertmann, 1988), quanto por sua atuação como fonte de energia, para os microorganismos responsáveis pela redução microbiana dos compostos oxidados (Lovley, 1995).

A redução do Fe no Latossolo Amarelo, no nível observado, não era esperada, tendo em vista a presença de goethita com alto grau de substituição isomórfica. Alguns autores têm postulado que a goethita é a fase mais estável e, portanto, menos susceptível à redução, particularmente a goethita com alto grau de substituição.

Observa-se que os teores elevados de Fe em solução nos horizontes superficiais dos Latossolos, principalmente no Latossolo Amarelo distrófico típico, podem representar importante fonte de Fe capaz de, sob condições temporariamente redutoras, fornecer $\mathrm{Fe}^{2+}$ para a solução do solo, o qual, por fluxo subsuperficial e lateral, poderá contribuir para a formação e manutenção de crostas lateríticas nas bordas dos platôs sob condições de maior aeração; e ainda ocorrer lixiviação de Fe do horizonte superficial para o horizonte subsuperficial e, daí, para o lençol freático, sob formas de complexos organo-ferruginosos.

A conseqüência pedogenética é a possível contribuição da ferrólise na destruição das argilas em superfície, formando-se, assim, um gradiente textural. É possível também que esse mecanismo, ocorrendo em maior magnitude, possa levar à gênese de horizontes espódicos, arenizados, a partir de um manto latossólico, conforme argumentam alguns autores (Andrade et al., 1997; Dubroeucq e Volkoff, 1998).

\section{Manganês}

Os teores de Mn em solução dos solos antropogênicos, Plintossolos, Alissolo e solos de várzea aumentaram rapidamente após a inundação à semelhança do que ocorreu com o Fe, atingindo os níveis mais elevados até o $43^{\circ}$-dia após a inundação (Figura 2). Nos Latossolos, os teores de Mn em solução, tanto nos horizontes superficiais quanto nos subsuperficiais, não atingiram níveis detectáveis por espectrometria de absorção atômica. O Mn está igualmente ausente ou ocorre em níveis muito baixos, nos Plintossolos e nos horizontes subsuperficiais do Alissolo e dos solos antrópicos, o que pode ser atribuído à ausência de formas oxídicas de Mn nesses solos.

Nos solos com maiores teores de Mn em solução, os níveis mais elevados foram alcançados no final da segunda semana, decrescendo rapidamente à semelhança do que se observou com o Fe, provavelmente em decorrência da elevação do $\mathrm{pH}$ da solução que promoveu sua precipitação.

De modo geral, os teores mais elevados de Mn em solução foram observados nos horizontes superficiais, certamente em decorrência da presença de formas menos estáveis e do maior conteúdo de matéria orgânica nesses horizontes. Porém, como

Tabela 2 - Coeficientes de correlação linear simples entre os teores de Al, Fe e Mn em solução e algumas das características dos solos estudados $(n=22)$

\begin{tabular}{lllllllllll}
\hline \hline Elementos & COT & FAF & FAH & Humina & \multicolumn{2}{ll}{ COT/argila Fe sol } & Feo & Mn sol & Mno & Al 3+ \\
\hline Al & 0.27 & -0.10 & -0.17 & -0.28 & -0.34 & -0.01 & & & $0.72^{* *}$ \\
Fe & 0.25 & 0.34 & 0.06 & 0.16 & 0.42 & & $0.57^{*}$ & 0.19 & & \\
Mn & 0.31 & 0.08 & 0.08 & 0.42 & 0.38 & 0.19 & & & $0.85^{* *}$ & \\
\hline \hline
\end{tabular}

COT - carbono orgânico total ; FAF - fração ácidos fúlvicos; FAH - fração ácidos húmicos; Feo - Fe extraído por oxalato de amônio; Mno - Mn extraído por oxalato de amônio. 

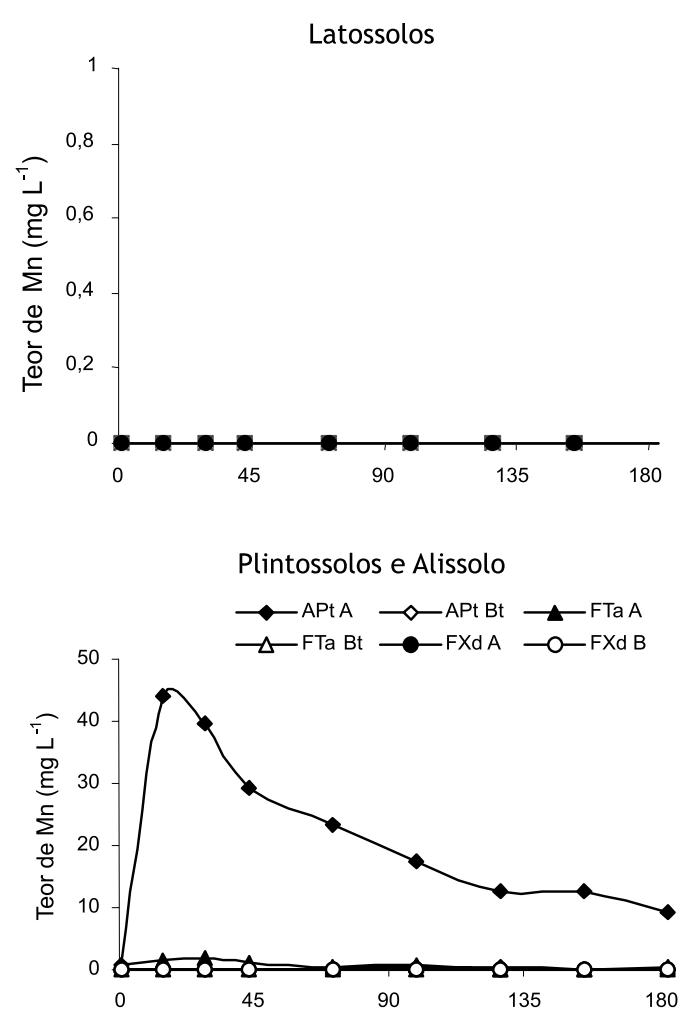

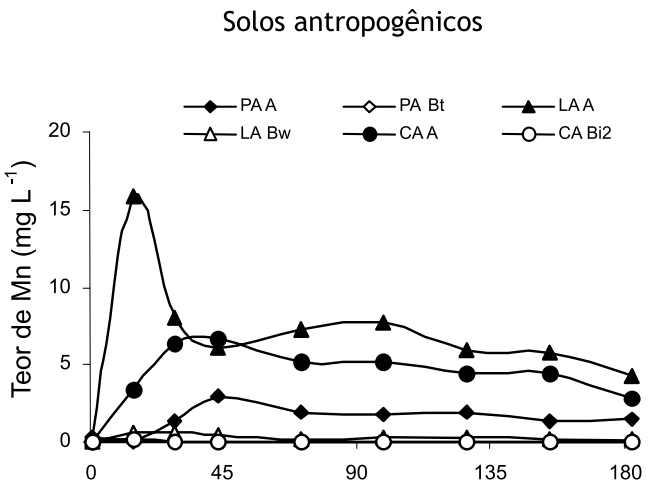

Solos de várzea

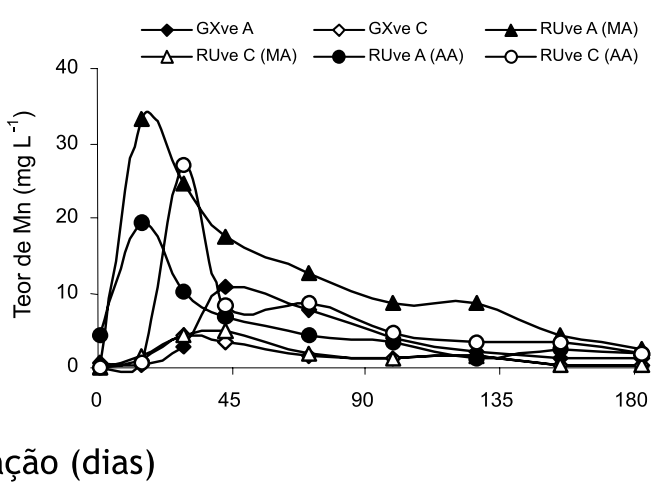

Figura 2 - Variação nos teores de Mn em solução durante o período de inundação.

variável isolada, apenas o teor de Mn extraído por oxalato de amônio apresentou correlação significativa e positiva com os teores máximos de Mn em solução (Tabela 2).

$\mathrm{O}$ maior teor de Mn em solução, cerca de $45 \mathrm{mg} \mathrm{L}^{-1}$, foi observado no horizonte superficial do Alissolo 15 dias após o início da inundação. Os solos de várzea, particularmente os Neossolos Flúvicos, também apresentaram altos teores de Mn em solução, com teores máximos entre 20 e $35 \mathrm{mg} \mathrm{L}^{-1}$.

\section{Alumínio}

O comportamento do Al em solução não apresentou diferença acentuada daquele apresentado pelo Fe, isto é, picos de máximo teor em solução foram alcançados geralmente entre o 1-e o 29- dia após a inundação (Figura 3). Contudo, excetuando-se os Latossolos, a maioria dos solos apresentou, por volta do $99^{\circ}$ - dia de inundação, um aumento significativo no teor de Al em solução, embora de menor magnitude que o primeiro.

De acordo com Olivie-Lauquet et al. (2001), o aumento do Al em solução estaria diretamente relacionado com o aumento dos teores de Fe e Mn. Isto é, com a solubilização dos compostos de Fe e Mn, o Al associado a esses óxidos também seria liberado em solução, aumentando sua mobilização. Além disso, com a solubilização dos compostos de Fe e de Mn, e conseqüente aumento dos teores desses elementos em solução, terá ocorrido um deslocamento de Al trocável, aumentando o seu teor em solução. Esta solubilização se sobreporia à tendência do $\mathrm{Al}^{3+}$ hidrolizar e precipitar hidróxidos de $\mathrm{Al}$ em valores de $\mathrm{pH}$ mais elevados, sob inundação.

Esse modelo foi capaz de explicar o comportamento observado até três meses de inundação, mas não no período subseqüente. Presume-se então, que a elevação do pH tenha tornado possível a solubilização de aluminossilicatos amorfos, elevando tanto os teores de Si quanto os de Al em solução.

Não foram observadas grandes diferenças nos teores de Al em solução entre os diversos grupos de solos. Os teores mais elevados foram observados nos horizontes subsuperficiais do Alissolo e do Plintossolo Argilúvico, onde o teor de Al trocável é mais elevado (Tabela 1). Os solos de várzea, com menores teores de Al trocável, apresentaram menores teores de $\mathrm{Al} \mathrm{em}$ solução. Como variável isolada, apenas o Al trocável apresentou correlação significativa com a concentração de Al em solução.

\section{Silício}

À semelhança da maioria dos outros elementos analisados, os maiores teores de Si em solução ocorreram entre o $1^{\circ}$-e o $29^{\circ}$ dia de inundação. Esses teores foram mais elevados nos solos de várzea, no Plintossolo Argilúvico e no Alissolo e menores 

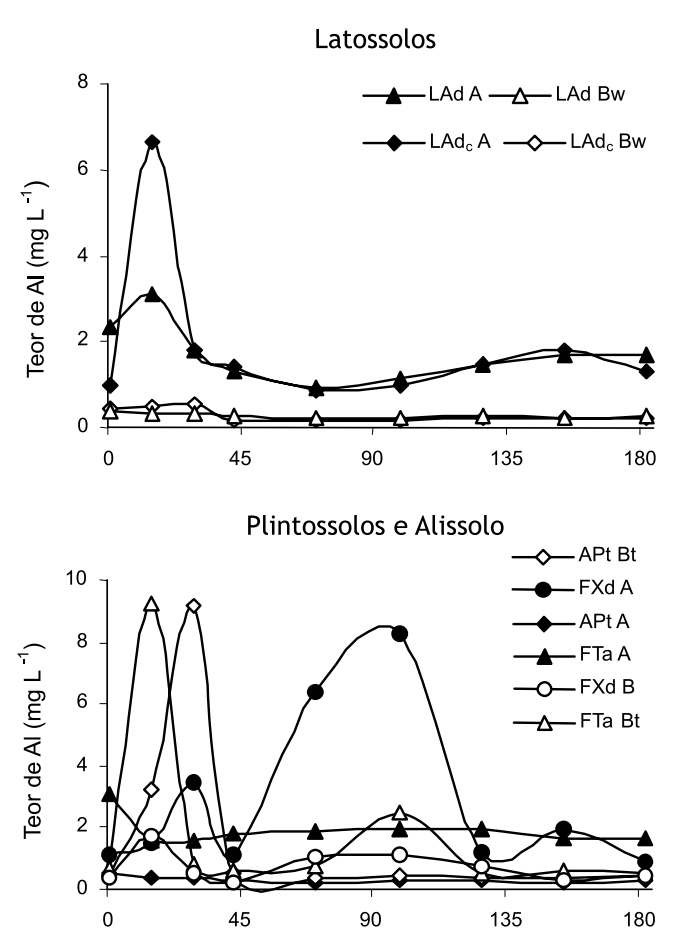
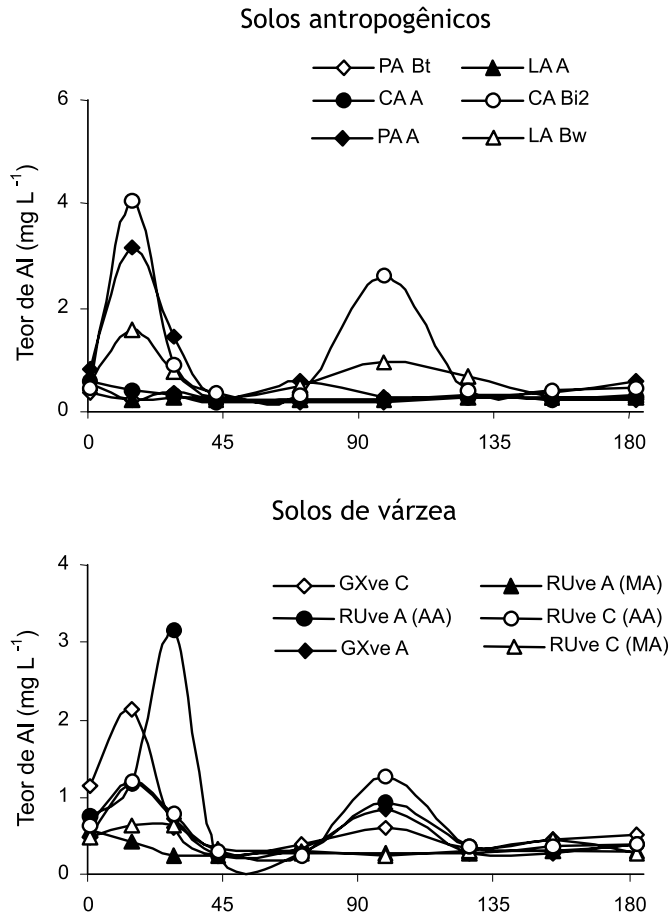

Tempo de inundação (dias)

Figura 3 - Variação nos teores de Al em solução durante o período de inundação.

nos Latossolos. Os teores máximos de Si em solução atingiram cerca de $30 \mathrm{mg} \mathrm{L}^{-1}$, nos solos de várzea e os menores cerca de $1 \mathrm{mg} \mathrm{L}^{-1}$ nos Latossolos (Figura 4). Esses resultados refletiram-se numa relação $\mathrm{Si} / \mathrm{Al}$ em solução mais alta nos solos de várzea e mais baixa nos Latossolos, em consistência com as suas características mineralógicas e com o seu grau de evolução.

A exemplo do Al, os teores de Si em solução tenderam a apresentar um novo pico de disponibilidade por volta do $99^{\circ}$ dia de inundação. Esse comportamento ocorreu em solos de todos os grupos, exceto nos Latossolos. Indicando uma variação na solubilização dos minerais silicatados ao longo do período de inundação, possivelmente, relacionada ao aumento do $\mathrm{pH}$, decorrente da redução de compostos de Fe e Mn, conforme comentado anteriormente, o que levaria a um aumento da solubilidade de compostos silicatados presentes nesses solos.

\section{Fósforo}

Diferente do que se observou para a maioria dos elementos avaliados, cujo comportamento geral foi caracterizado por um aumento inicial do teor em solução seguido por um declínio e estabilização, os teores de $\mathrm{P}$ em solução variaram continuamente ao longo do período de inundação, sendo essas variações menos acentuadas nos solos antropogênicos (Figura 5).

Em geral, os teores de P em solução foram baixos. Nos
Latossolos, Plintossolos e Alissolo foram inferiores a $0,5 \mathrm{mg} \mathrm{L}$ ${ }^{1}$. Nos solos antropogênicos e de várzea foram mais elevados, especialmente no horizonte subsuperficial do Latossolo Amarelo antrópico, excedendo a $2 \mathrm{mg} \mathrm{L}^{-1}$ (Figura 5).

O P em solução mostrou um pico de máxima disponibilidade entre o $15^{\circ}$ - e $043^{\circ}$ - dia, período que, de modo geral, coincidiu com a máxima disponibilidade de Fe e Mn em solução. No entanto, como variáveis isoladas, o Fe em solução, $\mathrm{o} \mathrm{Fe}_{\mathrm{o}}, \mathrm{o} \mathrm{Fe}_{\mathrm{d}}$ e suas relações não apresentaram correlações significativas com os teores de $\mathrm{P}$ em solução no período de inundação (Tabela 3).

Fosfatos orgânicos e inorgânicos não participam diretamente das reações redox, contudo, mudanças nas características químicas do solo resultantes dessas reações influenciam, acentuadamente, o comportamento do P em solos que sofrem inundação (Willett, 1991). Entre essas mudanças, a elevação do $\mathrm{pH}$, decorrente da redução de vários compostos, influencia diretamente a mobilização do $\mathrm{P}$.

O P mobilizado tem sido interpretado como resultante do aumento das cargas negativas dos óxidos e da competição entre os grupos $\mathrm{OH}^{-}$e os ânions fosfatos $\left(\mathrm{H}_{2} \mathrm{PO}_{4}^{-}\right)$por sítios de adsorção (Koski-Vähälä et al., 2001). Além disso, a redução e a conseqüente dissolução dos óxidos de Fe podem diminuir o número de sítios de adsorção de fosfato do solo durante o período inicial de inundação (Mello et al., 1992). Mais recentemente, tem-se considerado o efeito da concentração de Si influenciando a mobilização de P (Hartikainen et al., 1996; 


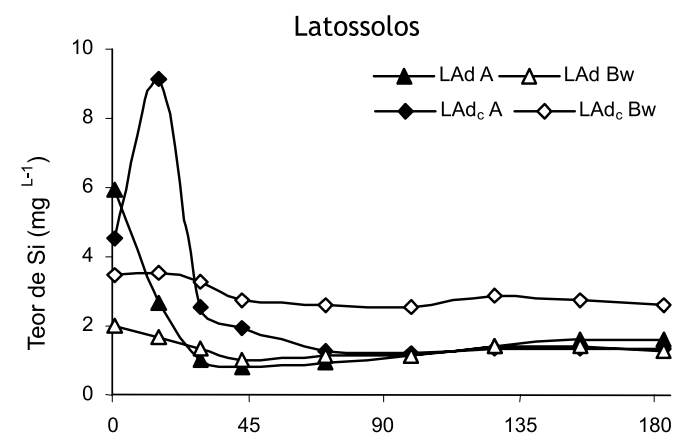

Plintossolos e Alissolo

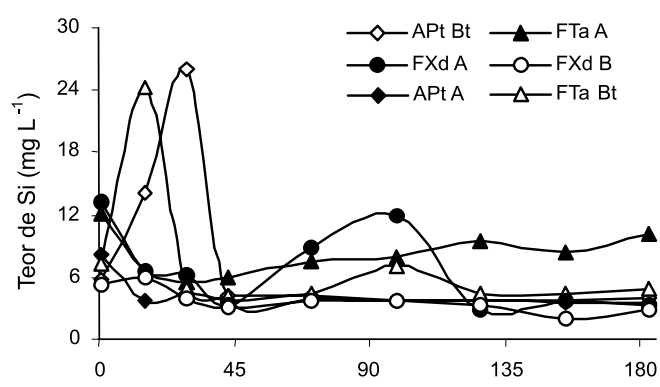

Solos antropogênicos

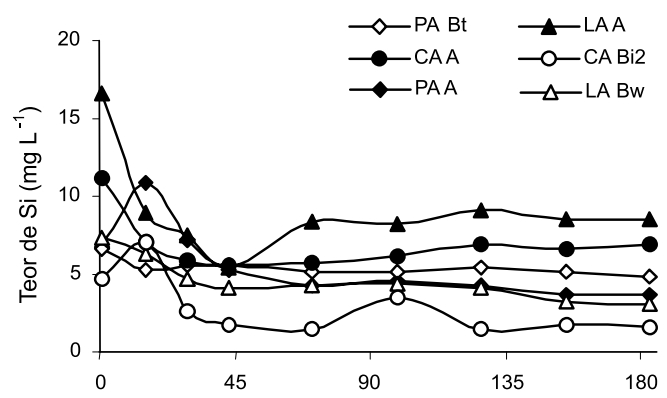

Solos de várzea

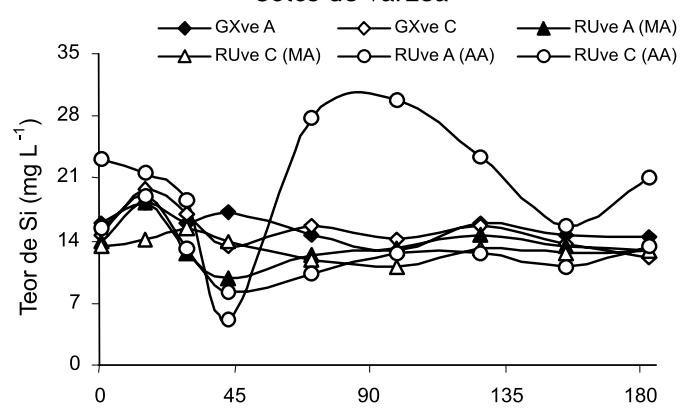

Tempo de inundação (dias)

Figura 4 - Variação nos teores de Si em solução durante o período de inundação.

Latossolos

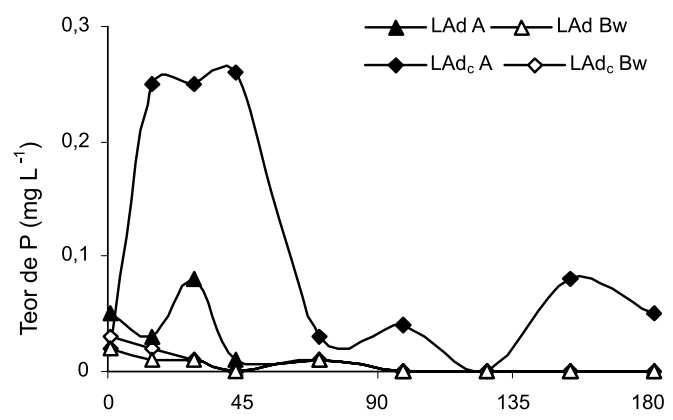

Plintossolos e Alissolo

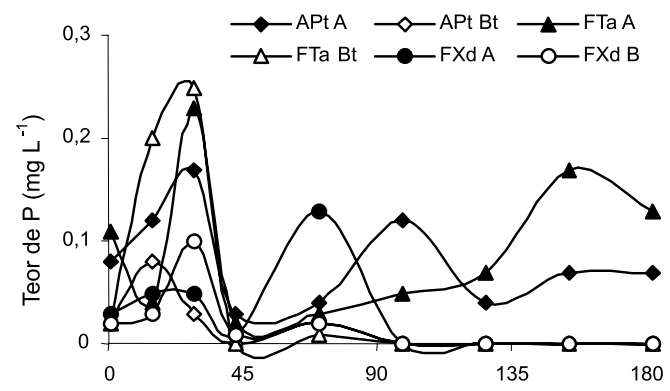

Solos antropogênicos

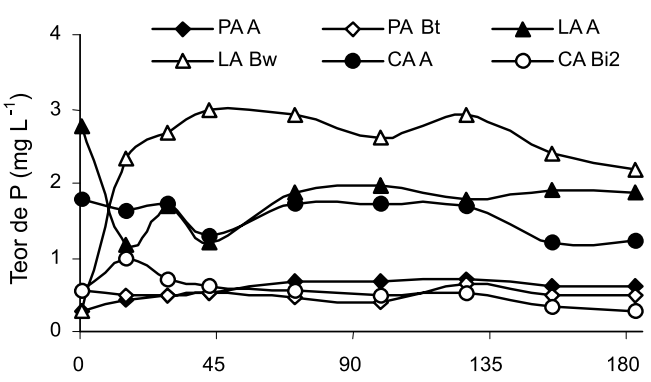

Solos de várzea

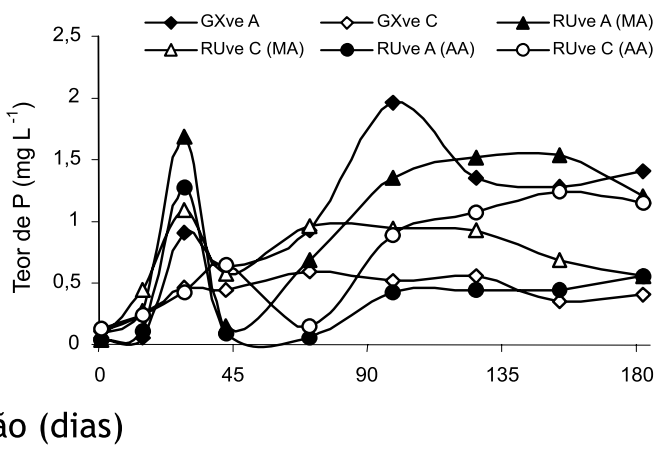

Figura 5 - Variação nos teores de $\mathrm{P}$ em solução durante o período de inundação. 


\section{ACTA AMAZONICA}

Tabela 3 - Coeficientes de correlação linear simples entre os teores de P e de Si em solução e algumas das características dos solos estudados $(n=22)$

\begin{tabular}{|c|c|c|c|c|c|c|c|c|c|c|c|c|c|c|}
\hline & $\mathrm{Al}_{45}$ & $\mathrm{Al}_{90}$ & $\mathrm{Si} / \mathrm{Al}_{45}$ & $\mathrm{Si} / \mathrm{Al}_{90}$ & $\mathrm{Fe}_{0}$ & COT & FAF & FAH & Hum. & P-Al & $\mathrm{P}-\mathrm{Fe}$ & P-FAF & P-FAH & Fe sol \\
\hline$P_{45}{ }^{(1)}$ & -0.33 & -0.26 & $0.52^{*}$ & $0.50^{*}$ & 0.20 & 0.40 & 0.03 & $0.41^{*}$ & 0.41 & $0.61^{* *}$ & $0.82^{* *}$ & $0.73^{* *}$ & $0.45^{*}$ & -0.05 \\
\hline $\mathrm{P}_{90}{ }^{(2)}$ & $-0.43^{*}$ & -0.28 & $0.55^{* *}$ & $0.53^{*}$ & 0.34 & 0.28 & -0.07 & 0.32 & 0.26 & $0.55^{* *}$ & $0.83^{* *}$ & $0.73^{* *}$ & 0.38 & -0.04 \\
\hline $\mathrm{Si}_{45}$ (3) & $0.44^{*}$ & 0.01 & 0.25 & 0.40 & $0.57^{* *}$ & -0.08 & -0.39 & -0.04 & -0.07 & - & - & - & - & - \\
\hline $\mathrm{Si}_{90}{ }^{(4)}$ & -0.22 & 0.09 & $0.47^{*}$ & $0.55^{* *}$ & $0.76^{* *}$ & -0.07 & -0.33 & -0.10 & -0.09 & - & - & - & - & - \\
\hline$P^{(5)}$ & -0.38 & -0.27 & $0.50^{* *}$ & $0.46^{*}$ & 0.15 & - & - & - & - & $0.66^{* *}$ & $0.90^{* *}$ & $0.82^{* *}$ & $0.45^{*}$ & -0.15 \\
\hline$P^{(6)}$ & -0.28 & -0.20 & $0.37^{*}$ & 0.29 & -0.12 & - & - & - & - & $0.75^{* *}$ & $0.81^{* *}$ & $0.85^{* *}$ & $0.59^{* *}$ & -0.24 \\
\hline
\end{tabular}

${ }^{(1)}$ teor máximo de $\mathrm{P}$ em solução até o $43^{\underline{2}}$ dia após a inundação; ${ }^{(2)}$ teor máximo de P em solução após $99^{-2}$ dia de inundação; ${ }^{(3)}$ teor máximo de Si em solução até o 43;

${ }^{(4)}$ teor máximo de Si em solução após 99º dia de inundação; ${ }^{(5)}$ teor médio de P em solução durante o período de inundação; ${ }^{(6)}$ teor de P extraído pelo extrator Mehlich-1 na TFSA dos solos estudados; COT - carbono orgânico total ; FAF - fração ácidos fúlvicos; FAH - fração ácidos húmicos; Feo - Fe extraído por oxalato de amônio; Mno - Mn extraído por oxalato de amônio; Hum - Humina.

Tuominen et al., 1998; Koski-Vähälä et al., 2001). Deve-se, contudo, registrar que a capacidade do silicato competir com o fosfato é altamente dependente de $\mathrm{pH}$, uma vez que o $\mathrm{pKa}$ do ácido silícico $\left(\mathrm{H}_{4} \mathrm{SiO}_{4}=9,7\right)$ é maior do que o do ácido ortofosfórico $\left(\mathrm{H}_{3} \mathrm{PO}_{4}^{4}\right)$.

Além disso, a solubilidade de minerais silicatados é muito baixa, mesmo em altos valores de $\mathrm{pH}$, e seus efeitos sobre a dinâmica de $\mathrm{P}$, possivelmente, são pequenos em ambiente natural. De acordo, com Koski-Vähälä et al. (2001), sedimentados biogênicos de diatomáceas (fonte de Si biogeoquimicamente ativa) e seus produtos de solubilização podem elevar o teor de Si em solução a níveis tão altos a ponto de influenciar na dessorção e, portanto, nos teores de P em solução.

O P liberado dos sedimentos, em resposta ao aumento do pH, é controlado por reações de dessorção e de readsorção. Os óxidos de Fe, recentemente precipitados, podem ser mais ativos na readsorção dos fosfatos do que os compostos férricos presentes antes da inundação (Koski-Vähälä et al., 2001). Esses mesmos autores observaram que a readsorção na fração Al-P influenciou significativamente a concentração de $P$ na água intersticial e que a presença de ligantes competitivos pode restringir a readsorção de $\mathrm{P}$ e manter altas concentrações de $\mathrm{P}$ em solução.

Todas as formas de $\mathrm{P}$ apresentaram correlação positiva e significativa com o teor de $\mathrm{P}$ em solução, tanto no período entre o $15^{\circ}$ e $43^{\circ}$ dia, quanto entre o $99^{\circ}$ e o $155^{\circ}$ dia, exceto o fósforo ligado à fração ácidos húmicos (P-FAH) entre o $99^{\circ} \mathrm{e} o$ 155- dia (Tabela 3). Os valores dos coeficientes foram maiores entre o P em solução e o P-Fe e menores entre o P em solução e o P-FAH, indicando maior participação da forma P-Fe na mobilização do P. O teor médio de $\mathrm{P}$ em solução durante o período de inundação apresentou correlação positiva e significativa com todas as formas de P e com o teor de P extraído pelo extrator Mehlich-1. Os valores de coeficientes de correlação mais elevados foram observados entre o teor médio de $\mathrm{P}$ em solução com o P-Fe e com o P-Mehlich, respectivamente, $0,90 \mathrm{e}$ 0,87 .
De modo geral, segundo Willett (1989), o segundo incremento do P em solução, observado entre o $99^{\circ}$ e o $155^{\circ}$ dia para a maioria dos solos, poderia estar associado à mineralização da matéria orgânica. No entanto, não se observou correlação significativa entre o carbono orgânico total e as várias frações das substâncias húmicas e o P em solução (Tabela 3). De modo semelhante, os teores de Si e de Al em solução não apresentaram correlação significativa com os teores de P em solução (valores não apresentados), apesar de alguns autores considerarem a possibilidade da competição entre o Si e o P em solução (Hartikainen et al., 1996; Tuominen et al., 1998; Koski-Vähälä et al., 2001).

Apesar dos teores de Si e de Al em solução não terem mostrado efeitos diretos sobre a dinâmica do $\mathrm{P}$, o teor de $\mathrm{P}$ em solução parece ser influenciado pela relação $\mathrm{Si} / \mathrm{Al}$ da solução (Tabela 3). Os valores das correlações entre P-solução e relação $\mathrm{Si} /$ Al da solução foram positivos e significativos, embora com valores de coeficientes menores do que aqueles obtidos entre P-solução e P-Fe, indicando que os processos de redução e oxidação química e bioquímica do Fe são mais importantes na dinâmica do $\mathrm{P}$, e que a relação $\mathrm{Si} / \mathrm{Al}$, que de certo modo reflete a riqueza em minerais filossilicatados 2:1 dos solos, tem influência secundária, possivelmente via processo de readsorção do $\mathrm{P}$ liberado em solução, pela redução dos compostos de Fe. Consistentemente, solos esmectíticos e menos oxídicos tendem a reter menos $\mathrm{P}$, em razão do menor teor de oxihidróxidos cristalinos de Fe e Al.

\section{ALTERAÇÕES NOS TEORES DOS CÁTIONS TROCÁVEIS}

Os cátions trocáveis, $\mathrm{Ca}^{2+}, \mathrm{Mg}^{2+}, \mathrm{K}^{+}$e $\mathrm{Na}^{+}$, não estão sujeitos a reações de oxirredução em condições ambientais, não sendo, portanto, diretamente influenciados pela inundação do solo. Todavia, grandes quantidades dos íons $\mathrm{NH}_{4}^{+}, \mathrm{Fe}^{2+}$ e $\mathrm{Mn}^{2+}$, liberados durante a inundação, podem deslocar consideráveis quantidades de $\mathrm{Ca}^{2+}, \mathrm{Mg}^{2+}, \mathrm{K}^{+} \mathrm{e} \mathrm{Na}^{+}$ dos sítios de troca (Sánchez, 1981), aumentando seus teores em solução. 


\section{ACTA AMAZONICA}

DINÂMICA DA MOBILIZAÇÃO DE ELEMENTOS EM SOLOS DA AMAZÔNIA SUBMETIDOS À INUNDAÇÃO

\section{Cálcio e magnésio}

$\mathrm{Ca}$ e Mg, de modo geral, revelaram comportamento similar àquele observado para Fe e o Mn, caracterizado por uma elevação inicial dos teores em solução, seguido de uma rápida redução, a partir do $29^{\circ}$ dia e estabilização após o $43^{\circ}$ dia (Figuras 6 e 7). $\mathrm{O}$ aumento nos teores de $\mathrm{Ca}$ e $\mathrm{Mg}$ em solução estaria diretamente relacionado ao aumento dos teores de Fe e Mn solúveis, além de $\mathrm{H}^{+}$, deslocando o Ca e o $\mathrm{Mg}$ do complexo de troca, os quais, em solução, apresentaram correlação significativa e positiva com os teores de Mn em solução, mas não com os de Fe em solução (Tabela 4).

Os teores de Ca são normalmente mais elevados nos horizontes superficiais, à exceção do Gleissolo. Os teores mais elevados de Ca em solução foram observados nos solos de várzea, especialmente nos Neossolos Flúvicos, alcançando

\section{Latossolos}

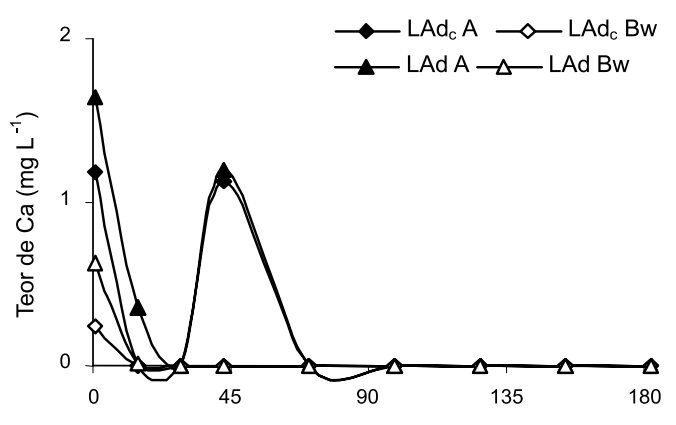

Plintossolos e Alissolo

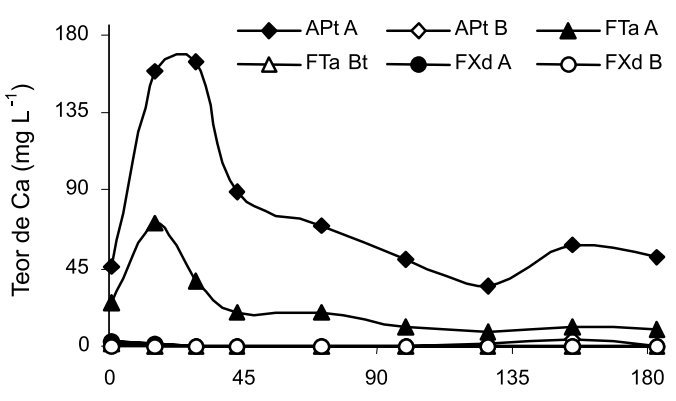

$215 \mathrm{mg} \mathrm{L}^{-1}$, seguido pelo Alissolo, Cambissolo com horizonte A antrópico, Latossolo Amarelo com horizonte A antrópico e Plintossolo Argilúvico abrúptico. Nos Latossolos, bem como nos horizontes subsuperficiais dos Plintossolos Háplico e Argilúvico, o Ca ocorre em níveis muito baixos.

Os teores de $\mathrm{Mg}$ são mais elevados nos horizontes superficiais, excetuando-se o Gleissolo e o Neossolo Flúvico do Alto Solimões, este último, especialmente, após o 99-dia. Os teores mais elevados de $\mathrm{Mg}$ em solução são observados nos solos de várzea, alcançando valores em torno de $37 \mathrm{mg} \mathrm{L}$ ${ }^{1}$, seguidos do Alissolo e dos solos antrópicos (Figura 7).

Ca e Mg em solução correlacionaram-se diretamente com os seus teores trocáveis, com o carbono orgânico total (COT), com as frações húmicas (exceto com a fração ácidos fúlvicos (FAF), para ambos e FAH para o Mg) e COT/argila. Os coeficientes de correlação e os níveis de significância, em todos os casos,

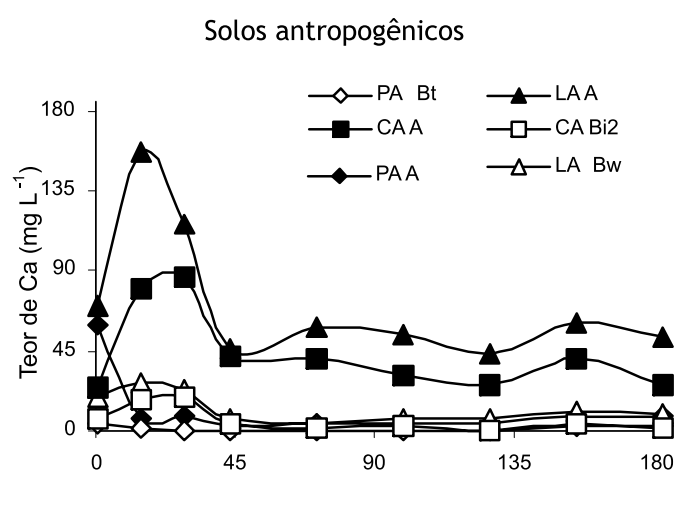

Solos de várzea

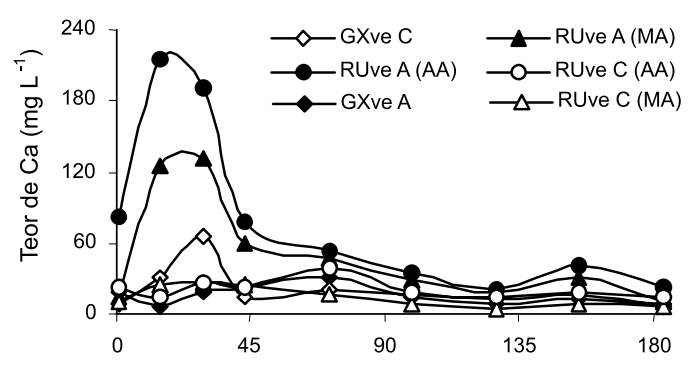

Tempo de inundação (dias)

Figura 6 - Variação nos teores de Ca em solução durante o período de inundação.

Tabela 4 - Coeficientes de correlação linear simples entre os teores de Ca, Mg, Na e K em solução e algumas das características dos solos estudados $(n=22)$

\begin{tabular}{|c|c|c|c|c|c|c|c|c|c|c|c|}
\hline Elementos & COT & FAF & FAH & Humina & COT/argila & Fe sol & Mn sol & $\mathrm{Ca}^{2+}$ & $\mathrm{K}^{+}$ & $\mathrm{Mg}^{2+}$ & $\mathrm{Na}^{+}$ \\
\hline$\overline{\mathrm{Ca}}$ & $0.65^{* *}$ & 0.20 & $0.46^{*}$ & $0.71^{* *}$ & $0.57^{* *}$ & 0.30 & $0.74^{* *}$ & $0.69^{* *}$ & & & \\
\hline K & $0.78^{* *}$ & 0.33 & $0.65^{* *}$ & $0.75^{* *}$ & $0.76^{* *}$ & $0.61^{* *}$ & 0.25 & & $0.62^{* *}$ & & \\
\hline$M g$ & $0.44^{*}$ & -0.05 & 0.29 & $0.46^{*}$ & $0.45^{*}$ & 0.36 & $0.70^{* *}$ & & & $0.72^{* *}$ & \\
\hline $\mathrm{Na}$ & 0.40 & -0.03 & 0.26 & 0.32 & 0.42 & $0.60^{* *}$ & 0.42 & & & & $0.63^{* *}$ \\
\hline
\end{tabular}

COT - carbono orgânico total ; FAF - fração ácidos fúlvicos; FAH - fração ácidos húmicos; Feo - Fe extraído por oxalato de amônio; Mno - Mn extraído por oxalato de amônio. 

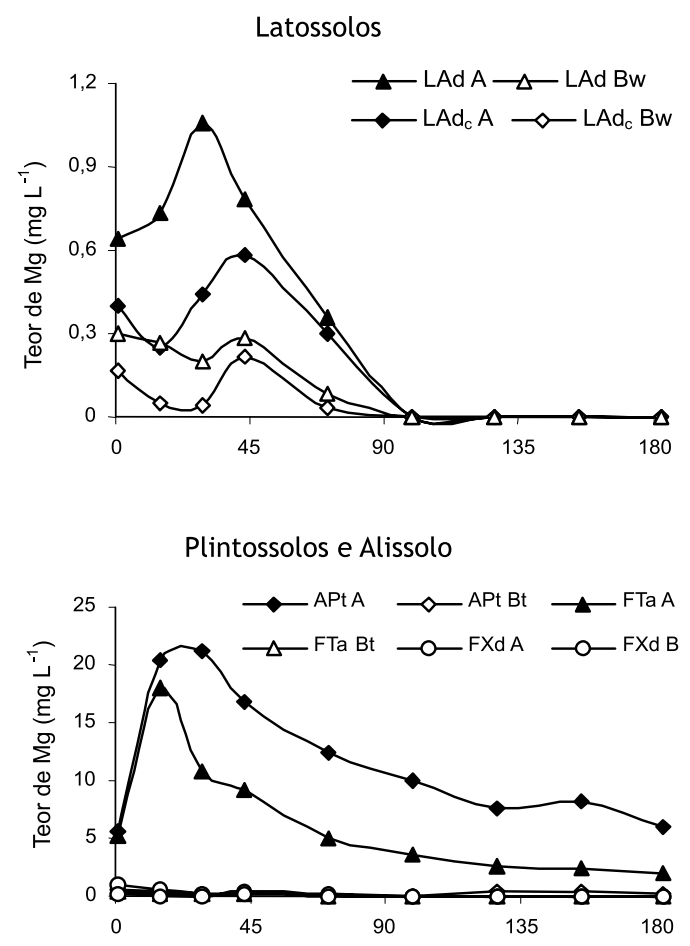

Solos antropogênicos
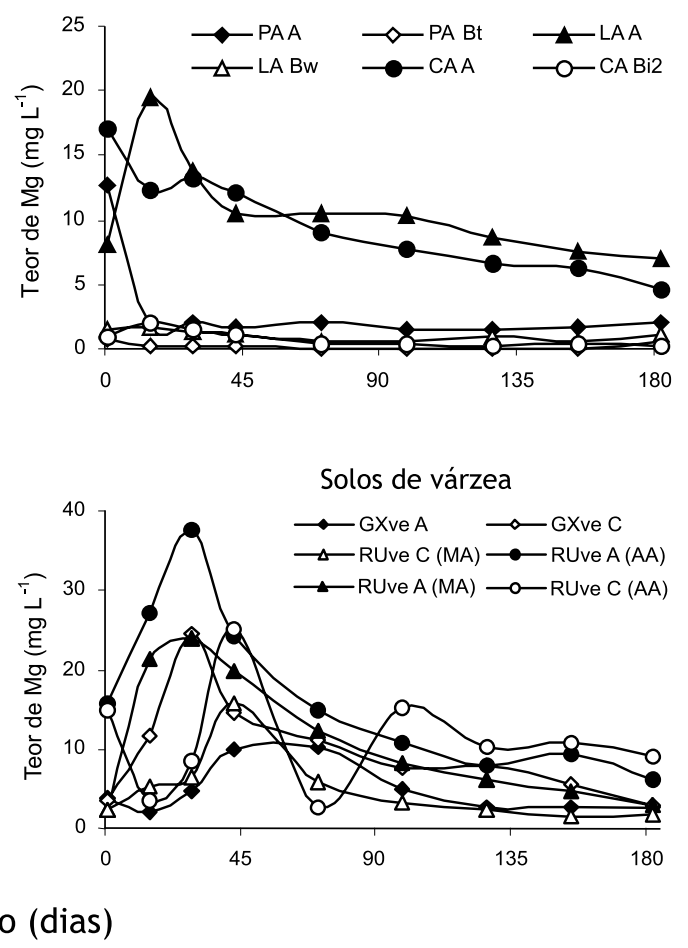

Figura 7 - Variação nos teores de Mg em solução durante o período de inundação.

são maiores entre o Ca em solução e as variáveis consideradas, do que essas e o Mg em solução (Tabela 4).

\section{Sódio e potássio}

De modo geral, o teor de Na em solução foi mais elevado imediatamente após a inundação, reduzindo-se progressivamente após o primeiro dia. Os teores em solução, comumente mais elevados nos horizontes superficiais, não excederam a $10 \mathrm{mg} \mathrm{L}^{-1}$. Os teores mais elevados foram observados nos solos de várzea, contudo a diferença entre os solos é menos acentuada para o $\mathrm{Na}$ do que para os demais elementos em geral (Figura 8).

Correlações significativas e positivas foram observadas entre o teor de Na em solução e os teores de Na trocável e de Fe em solução. Para as demais variáveis consideradas, inclusive Mn em solução, COT e frações de substâncias húmicas, não houve correção significativa entre essas e o teor de $\mathrm{Na}$ em solução (Tabela 4).

A variação no teor de $\mathrm{Kem}$ solução mostrou-se menor ao longo do tempo de inundação, quando comparada com a variação no teor dos demais elementos. Os teores do K foram, invariavelmente, mais elevados nos horizontes superficiais do que nos subsuperficiais, não excedendo, no entanto, a $10 \mathrm{mg}$ $\mathrm{L}^{-1}$. Verificaram-se teores mais elevados no Neossolo Flúvico do Alto Solimões, no Plintossolo Argilúvico abrúptico e no Cambissolo com horizonte A antrópico (Figura 9).
Observaram-se correlações significativas e positivas do teor de K em solução com o seu teor trocável, com o Fe em solução e com o COT e as frações de substâncias húmicas, exceto FAF e relação COT/argila. Não houve correlação significativa entre o teor de K em solução e o teor de Mn em solução. (Tabela 4).

De modo geral, os resultados observados neste estudo mostram que o processo de inundação resultou em um aumento significativo em solução de todos elementos avaliados. Essa solubilização poderá resultar na perda total de elementos mais móveis, ou sua precipitação e deposição em outra parte do perfil, em um processo de translocação, influenciando diretamente na pedogênese de alguns solos. Certamente, provocará alterações na absorção de elementos pelas plantas, especialmente naquelas adaptadas aos ambientes sujeitos à inundação.

Necessitam-se de mais estudos sobre a variação sazonal dos teores de nutrientes e outros elementos, em especial nos solos de várzea, para que se possa mais bem compreender alterações decorrentes da inundação, e o estabelecimento de indicadores ambientais mais precisos das possíveis implicações ambientais e agronômicas da inundação.

\section{CONCLUSÕES}

A inundação influenciou a dinâmica dos elementos avaliados, com aumento da mobilização da maioria, principalmente, nas primeiras semanas. 


\section{ACTA \\ AMAZONICA}

DINÂMICA DA MOBILIZAÇÃO DE ELEMENTOS EM SOLOS

DA AMAZÔNIA SUBMETIDOS À INUNDAÇÃO

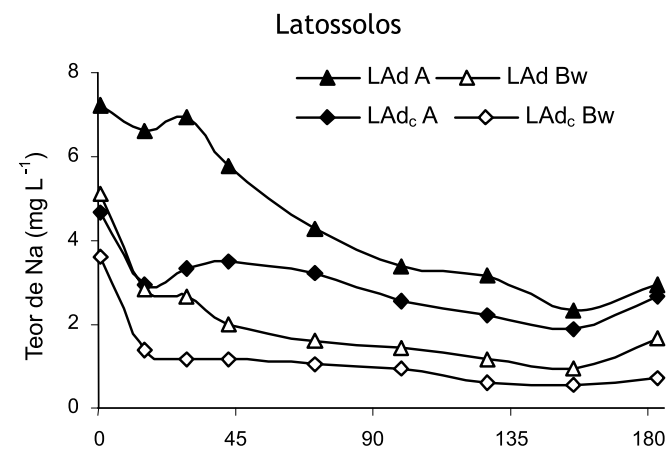

Plintossolos e Alissolo

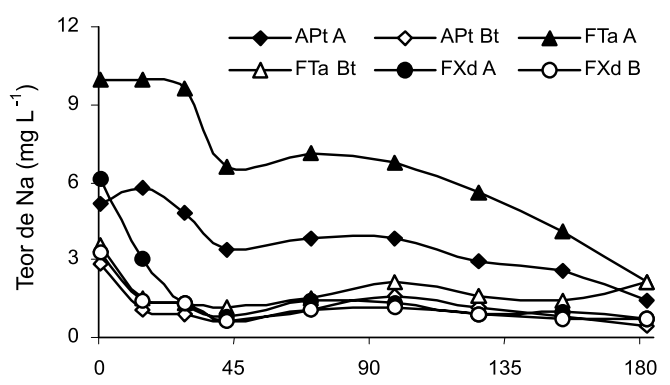

Solos antropogênicos

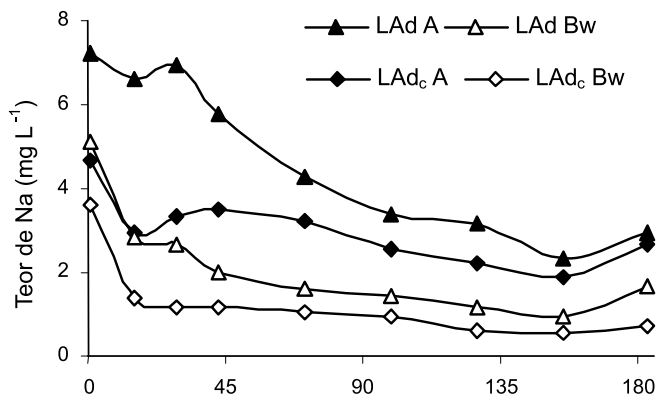

Solos de várzea

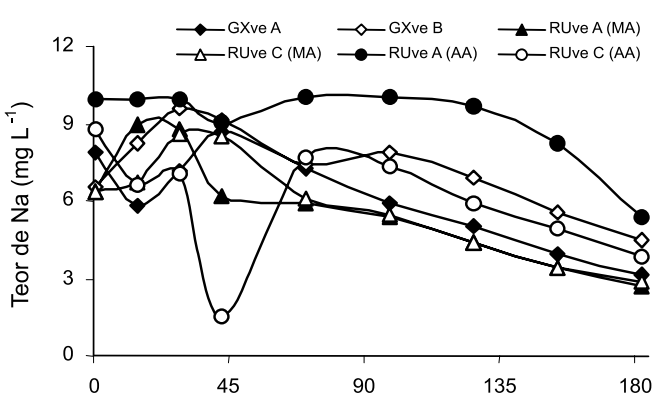

Tempo de inundação (dias)

Figura 8 - Variação nos teores de Na em solução durante o período de inundação.

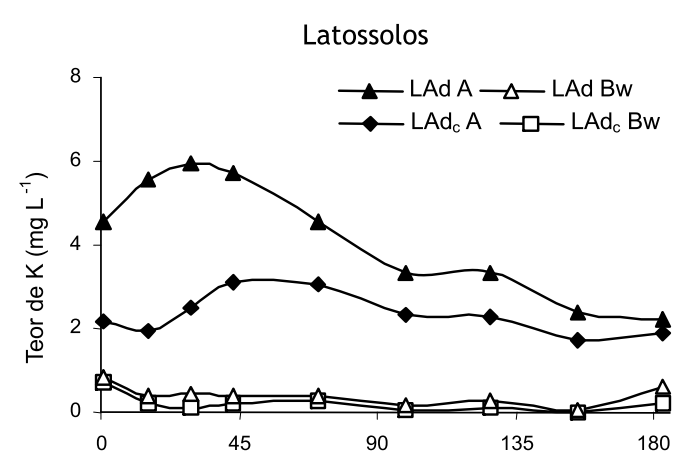

Plintossolos e Alissolo

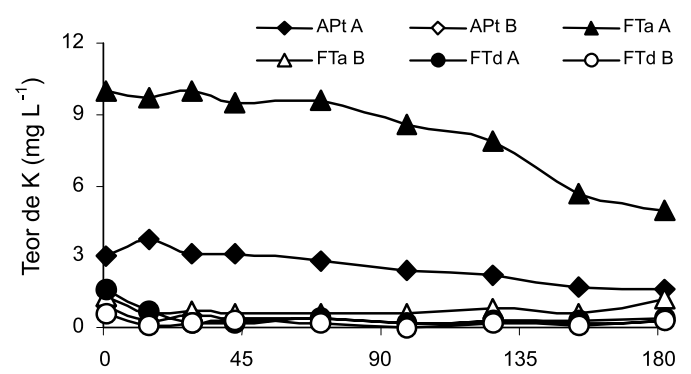

Solos antropogênicos
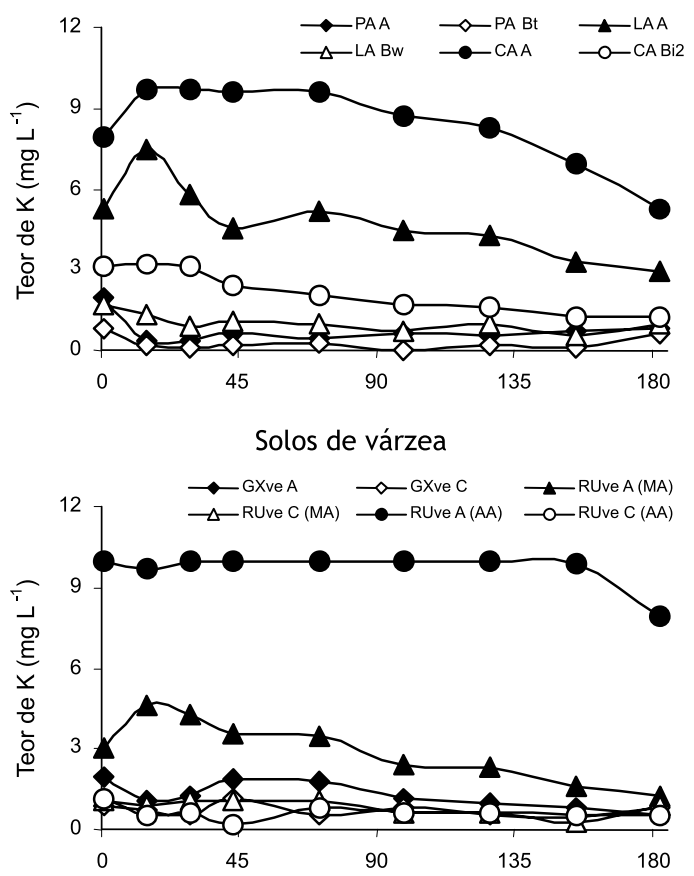

Tempo de inundação (dias)

Figura 9 - Variação nos teores de K em solução durante o período de inundação. 


\section{ACTA \\ AMAZONICA}

DINÂMICA DA MOBILIZAÇÃO DE ELEMENTOS EM SOLOS

DA AMAZÔNIA SUBMETIDOS À INUNDAÇÃO
Os teores de Fe em solução foram mais elevados para os solos mais ricos em Fe amorfo. Em amostras com baixos teores de Fe amorfo e baixo conteúdo de matéria orgânica a mobilização do Fe foi muito reduzida .

O teor de P em solução foi influenciado por todas as formas de P. O P-Fe foi a forma que maior influência exerceu sobre a teor de P solúvel.

Os teores de $\mathrm{Ca}^{2+}, \mathrm{Mg}^{2+}, \mathrm{K}^{+}$e $\mathrm{Na}^{+}$, em solução, foram diretamente influenciados por seus respectivos teores trocáveis, bem como pela cinética do Fe e do Mn.

\section{BIBLIOGRAFIA CITADA}

Andrade, H.; Schaefer, C.E.G.R.; Demattê, J.L.I.; Andrade, F.V. 1997. Pedogeomorfologia e micropedologia de uma seqüência Latossolo-Areia Quartzosa Hidromórfica sobre rochas cristalinas do Estado do Amazonas. Geonomos, 5:5566.

Bohn, H.L. 1970. Redox potentials. Soil Science, vol. 112, no. 1: $39-45$.

Coffin, D.E. 1963. A method for the determination of free iron in soils and clays. Can. J. Soil Sci., Ottawa, 43:7-17.

Dubroeucq, D.; Volkoff, B. 1998. From oxisols to spodosols and histosols: evolution of the soil mantles in the Rio Negro basin (Amazonia). Catena, 32:245-280.

Empresa Brasileira de Pesquisa Agropecuária. Centro Nacional de Pesquisa de Solos.1997. Manual de métodos de análise de solo. Rio de Janeiro. 212pp.

Empresa Brasileira de Pesquisa Agropecuária. Centro Nacional de Pesquisa de Solos.1999. Sistema Brasileiro de Classificação de Solos. EMBRAPA Solos. Rio de Janeiro. 412pp.

Hartikainen, H.; Pitkänen, M.: Kairesalo, T.; Tuominen, L. 1996. Co-occurrence and potential chemical competition of phosphorus and silicon in lake sediment. Wat. Res., 30(10):2472-2478.

Jugsujinda, A.; Delaune, R.D.; Patrick Jr., W.H. 1987. A comparison microbially and chemically reducible iron in three soils. Plant and Soil, 103:281-284.

Koski-Vähälä. J.K.; Hartikainen, H.; Tallberg, P. 2001. Phosphorus Mobilization from various sediment pools in response to increased $\mathrm{pH}$ and silicate concentration. J. Environm. Qual., 30:546-552.

Kuo, S. .1996. Phosphorus. In: Methods of soil analysis. Part 3. Chemical methods. D.L. Sparks et al. (eds.). Soil Science Society of American. p.869-919.

Liesack, W.; Schnell, S.; Revsbech, N.P. 2000. Microbiology of flooded rice paddies. FEMS Microbiology Reviews, 24:625645.

Lovley, D.R. 1995. Microbial reduction of iron, manganese, and other metals. Adv. Agron., 54:175-231.
McLatchey, G.P.; Reddy, K.R. 1998. Regulation of matter decomposition and nutrient release in a wetland soil. $J$. Environ. Qual., 27:1268-1274.

Mello, J.W.V.; Fontes, M.P.F.; Ribeiro, A.C.; Alvarez V., V.H. 1992. Inundação e calagem em solos de várzea: I. alterações em pH, Eh e teores de $\mathrm{Fe}^{2+}$ e $\mathrm{Mn}^{2+}$ em solução. R. Bras. Ci. Solo, Campinas, 16:309-317.

Munch, J.C.; Ottow, J.C.G. 1980. Preferencial reduction of amorphus to crystalline iron oxides by bacterial activity. Science, 129:15-21.

Olivie-Lauquet, G.; Gruau, G.; Dia, A.; Riou, C.; Jaffrezic, A.; Henin, O. 2001. Release of trace elements in wetlands: role of seasonal variability. Wat. Res. 35(4): 943-952.

Phillips, E.J.P.; Lovley, D.R.; Roden, E.E. 1993. Composition of non-microbially reducible Fe(III) in aquatic sediments. Appl. Environ. Microbiol., 59:2727-2729.

Ponnamperuma, F.N. 1972. The chemistry of submerged soils. Adv. Agron., New York, 24:29-96.

Ponnamperuma, F.N.; Tianco, E.M.; Loy, T. 1967. Redox equilibria in flooded soils: I. the iron hydroxide systems. Soil Science, 103(6)374-382.

Reddy, K.R.; Patrick Jr., W.H. 1975. Effect of alternate aerobic and anaerobic conditions on redox potential, organic matter decomposition and nitrogen loss in a floded soil. Soil Biol. Biochem., 7:87-94.

Roden, E.E.; Zachara, J.M. 1996. Microbial reduction of crystalline iron(III) oxides: Influence of oxide surface area and potential for cell growth. Environ. Sci. Technol., 30:16181628.

Sánchez, P.A. 1981. Suelos del trópico: caracteristicas y manejo. San José: IICA. 634pp.

Schwertmann, U. 1964. Differenzierung der eisenoxide des bondes durch photochemische extraktion mit saurer ammonium-oxalat-Lösung. Z. Pflanzenernahr. Bodenk, 105:194-202.

Schwertmann, U. 1966. Inhibitory effect of soil organic matter on the crystallization of amorphus ferric hidroxide. Nature, 212:645-646.

Schwertmann, U. 1988. Occurrence and formation of iron oxides in various pedoenviroments. In: Stucki, J.W., Goodman, B.A., Schwertmann, U. (eds.) Iron in soils and clay minerals. Dordrecht, D. Reidel. p.267-308.

Tuominen, L.; Hartikainen, H.; Kairesalo, T.; Tallberg, P. 1998. Increased bioavailability of sediment phosphorus due to silicate enrichment. Wat. Res., 32(7):2001-2008.

Willett, I.R. 1989. Causes and prediction of changes in extractable phosphorus during flooding. Aust. J. Sois Res., 27:45-54. 
Willett, I.R. 1991. Phosphorus dynamics in acidic soils that undergo alternate flooding and drying. In: Rice production on acid soils of the tropics. Deturck, P., Ponnamperuma, F.N. (eds.). Institute of Fundamental Studies, Kandy, Sri Lanka. p. 43-49.

Yeomans, J.C.; Bremner, J.M. 1988. A rapid and precise method for routine determination of organic carbon in soil. Commun. in Soil Sci. Plant Anal., 19(13):1467-1476.
Yu, T.R. 1991. Physico-chemical properties of acid soils of the tropics relation to rice growth. In: Rice production on acid soils of the tropics. Deturck, P., Ponnamperuma, F.N. (eds.). Institute of Fundamental Studies, Kandy, Sri Lanka. p. 33-42.

RECEBIDO EM 14/09/2004

ACEITO EM 20/07/2005 